\title{
Ostracoda (Crustacea) from the Archipelago of São Pedro and São Paulo, Equatorial Atlantic, with emphasis on a new Hemicytheridae genus
}

\author{
João C. Coimbra ${ }^{1}$, Silvia R. Bottezini² \& Cláudia P. Machado ${ }^{3}$ \\ 1. Universidade Federal do Rio Grande do Sul, Departamento de Paleontologia e Estratigrafia, Caixa Postal 15001, 91501-970, Porto Alegre, RS, Brazil. (joao.coimbra@ufrgs.br) \\ 2. Universidade Regional Integrada do Alto Uruguai e das Missões, Campus de Frederico Westphalen, Rua Assis Brasil, 709, 98400-000, Frederico Westphalen, RS, Brazil. \\ 3. Universidade de Caxias do Sul, Campus Universitário da Região dos Vinhedos, Alameda João Dal Sasso, 800, 95700-000, Bento Gonçalves, RS, Brazil.
}

\begin{abstract}
The present study is a further contribution to the systematic knowledge of the shallow water marine ostracodes from the Brazilian oceanic islands. A total of 14 species belonging to 10 genera and eight families is herein identified. One new genus and species are described and illustrated: Berguecythere insularis gen. nov., sp. nov. In addition to this new taxon, the abundant species Loxocorniculum tricornatum Krutak, 1971, widely distributed in recent sediments in the Gulf of Mexico, Caribbean, north and northeast of Brazil and the Rocas Atoll, along with the cosmopolitan tropical ostracode Triebelina sertata Triebel, 1948, were also identified at specific level. The remaining 11 species were left at the genus level, and should provide new species. Ecological, zoo- and paleozoogeographical aspects were also briefly discussed.
\end{abstract}

KEYWORDS. Taxonomy, new species, morphology, Atlantic Ocean.

RESUMO. Ostracoda (Crustacea) do Arquipélago de São Pedro e São Paulo, Atlântico Equatorial, com ênfase em novo gênero de Hemicytheridae. O presente estudo é uma contribuição para o conhecimento da sistemática dos ostracodes marinhos rasos das ilhas oceânicas brasileiras. Um total de 14 espécies pertencentes a 10 gêneros e oito famílias é aqui identificado. Um novo gênero e espécie são descritos e ilustrados: Berguecythere insularis gen. nov., sp. nov. Além desse novo táxon, foram também identificados Loxocorniculum tricornatum Krutak, 1971, espécie abundante amplamente distribuída em sedimentos recentes do Golfo do México, Caribe, norte e nordeste do Brasil e no Atol das Rocas, e o ostracode cosmopolita tropical Triebelina sertata Triebel, 1948. As 11 espécies restantes foram deixadas em nível de gênero e devem fornecer novas espécies. Aspectos ecológicos e zoo- e paleozoogeográficos também foram brevemente discutidos.

PALAVRAS-CHAVE. Taxonomia, nova espécie, morfologia, Oceano Atlântico.

The Archipelago of São Pedro and São Paulo (ASPSP) was discovered in 1511 when a Portuguese fleet consisting of six caravels bound for India then recorded its first shipwreck. Darwin, in his trip on the HMS Beagle around the world, visited this small archipelago in 1832, and he marveled at what he saw. He listed all the fauna he could find, but not a single plant or even lichen could be found by him. Since the last century, this archipelago is considered a site of ecological interest and also strategic for the Brazilian territory. On June 25, 1998, the Brazilian government inaugurated a scientific station in the Belmont islet, the largest of all, starting a successful research program called PROARQUIPELAGO (MARINHA DO BRASIL/ SECIRM, 2009).

As discussed by many authors, high levels of endemism in oceanic islands and islets can be a result of allopatric speciation due to physical isolation. The deep ocean is an effective barrier to the dispersal of benthic invertebrates with life cycles restricted to shallow waters such as benthic ostracodes, which are not good swimmers and do not have a planktotrophic larval stage.

There is consensus among most authors (e.g. LARWOOD \& WHATLEY, 1993), that areas isolated over millions of years have higher levels of endemism than those with continual or intermittent shallow submarine connections with the mainland or other islands. Although the other three Brazilian oceanic islands, i.e., Fernando de Noronha Archipelago, Trindade/Martim Vaz and the Rocas Atoll have submarine connections with the mainland (see CoImbra \& CARreÑo, 2012), the ASPSP fits well in the first case since it is distant $\sim 1,100 \mathrm{~km}$ from the coast of Brazil and its rocks rise from a depth of $\sim 3,800 \mathrm{~m}$ (Мотокі et al., 2009). This isolation is a major contributor to the high endemism among benthic invertebrates in this archipelago (see AMARAL et al., 2009; Moraes et al., 2009; Oliveira et al., 2009). However, little is known about its ostracode fauna (see ANTONiETto et al., 2012).

This study is a contribution to the knowledge of the ostracodes from the ASPSP, with emphasis on the description of the endemic taxon Berguecythere insularis gen. nov., sp. nov. Furthermore, are identified and illustrated the remaining species (most in open nomenclature) recorded in this archipelago. Finally, aspects of the ecology and zoogeography of these microcrustaceans are also briefly discussed.

\section{MATERIAL AND METHODS}

The Archipelago of São Pedro and São Paulo (ASPSP) consists of a few islets, being the four largest (Cabral, São Pedro, São Paulo and Belmonte) arranged in a semicircle forming a shallow cove with maximum depth of $\sim 15 \mathrm{~m}$ (Figs 1, 2), whose bottom is composed by bioclastic sediments and archipelago weathered rocks. In fact, this archipelago is the top of a submarine morphological elevation whose base is at $\sim 3,800$ m water depth. It is the only location on the Atlantic Ocean where the abyssal mantle is exposed above sea level, since it 


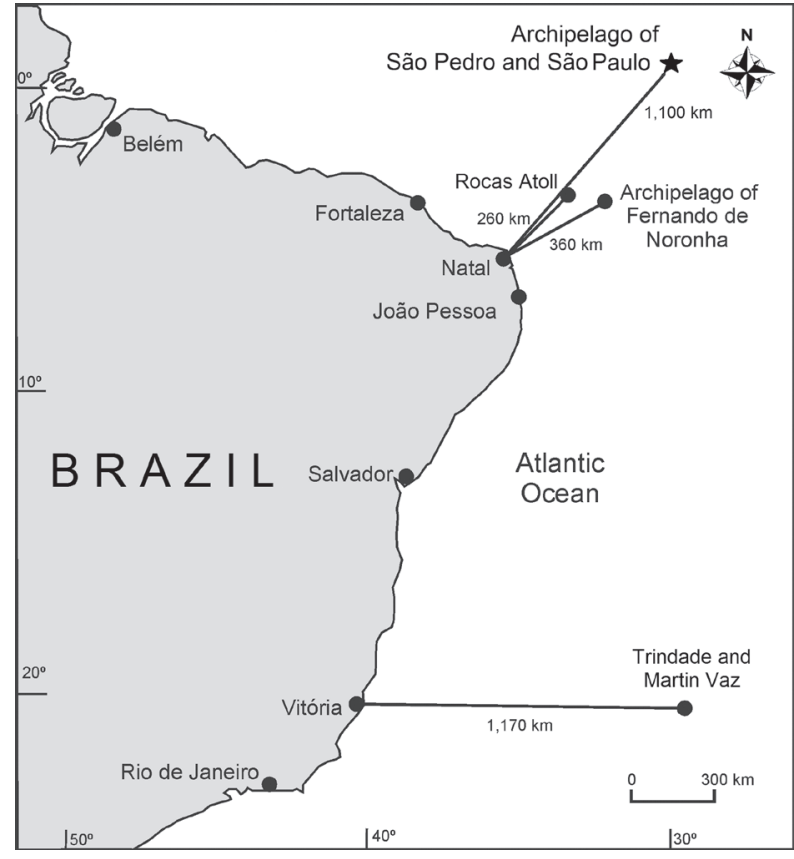

Fig. 1. Location map of the Brazilian oceanic islands and archipelagos showing the distance to the nearest continental cities (modified from Almeida, 2006; CoImBra \& CARreÑo, 2012).

is not formed by volcanic rocks, but by plutonic ones (BonATTI, 1990; HeKINIAN et al., 2000). It covers an emerged area of approximately 1.7 ha, with maximum length of $\sim 400 \mathrm{~m}$ and a maximum height of $18 \mathrm{~m}$ above sea level (EDWARds \& LUBbock, 1983; Sichel et al., 2008). The ASPSP is devoid of beaches and drinking water, and only its main islet has a very few developed kind of undergrowth.

This archipelago is separated from the Brazilian continental shelf by deep ocean, whose depths range from 2,000 to $4,000 \mathrm{~m}$, and in its nearest surroundings the top of some seamounts are located just $100 \mathrm{~m}$ below the surface (Moraes \& Muricy, 2007). The South Equatorial Current, that is the main current in this area, flows superficially from east to west with a maximum speed of $1.5 \mathrm{~m} \cdot \mathrm{s}^{-1}$. Below it, between 40 and $150 \mathrm{~m}$ depth, the South Equatorial Undercurrent carries water in the opposite direction, with speed of up to $0.7 \mathrm{~m} \cdot \mathrm{s}^{-1}$ (Stramma \& England, 1999). Together, these two currents generate a pattern of high complexity with a great influence on the island ecosystem, causing nutrient enrichment of waters (CAMPOS et al., 2009).The average temperature of the surface water varies between $28.3^{\circ} \mathrm{C}$, in summer, and $26.4^{\circ} \mathrm{C}$, in winter (MACEDO-SOARES et al., 2009).

The ostracodes for this study come from the analysis of 22 samples (four barren for ostracodes) hand collected in three different areas in the cove of the ASPSP by free diving at depths ranging from 2 to $11 \mathrm{~m}$ (Fig. 2; Tab. I). All the material examined was collected by Cláudia Pinto Machado, Fernando Erthal and Sandro Monticelli Petró, with the help of the Brazilian Navy crew, during 15 days in July/August 2010. In the field, all samples were stored in plastic bottles and fixed in alcohol $70 \%$.

In order to collect Ostracoda on algae, wherever possible some bunches were wrapped within a plastic bag and this portion of the algae was cut off from the plant. Unfortunately, together with the algae some sediment was collected. This was due to the rough waters of the cove and also for our limited experience in field work in such bad conditions. Furthermore, it is noteworthy that even ostracodes that were living on bottom sediments may occasionally float after death and be recovered with the water that surrounds the fronds of algae. For these reasons many isolated valves and even

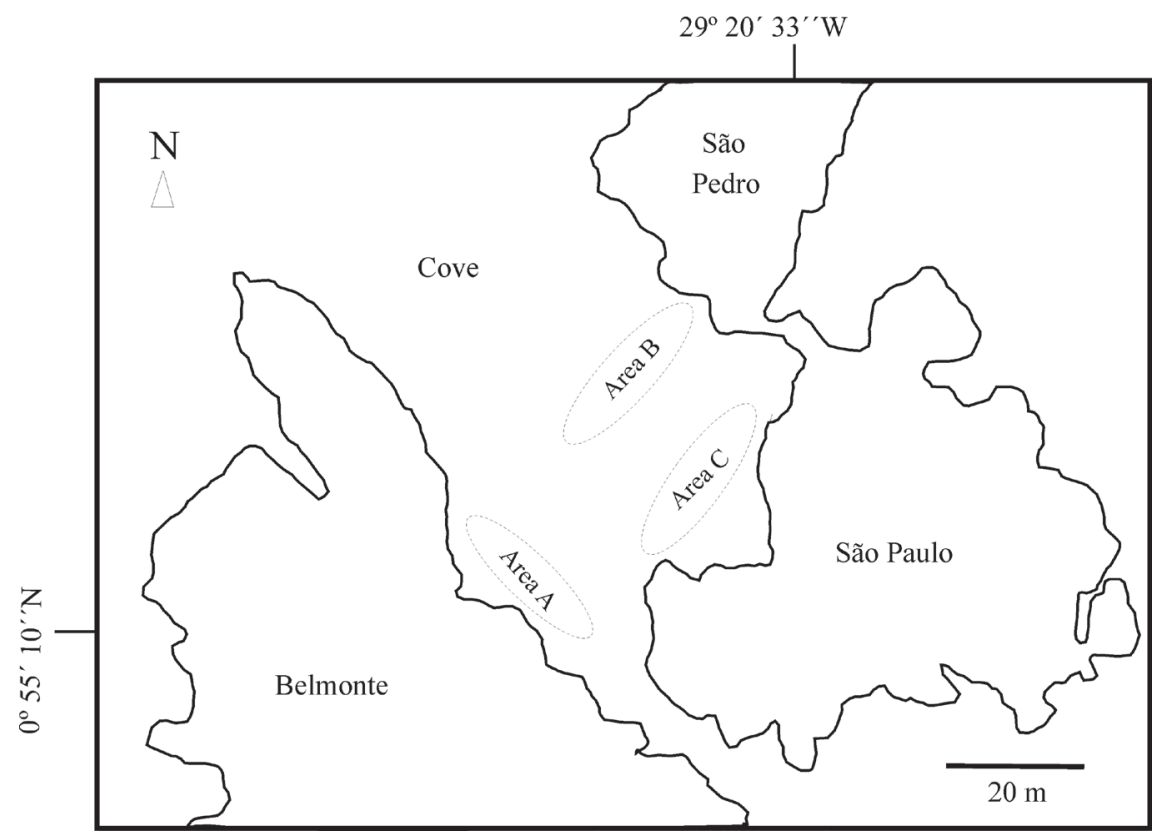

Fig. 2. Sampling areas in the cove of the Archipelago of São Pedro and São Paulo, Equatorial Atlantic. For more details see Table I. 
Tab. I. Number, location, substrate and depth of samples recovered from the cove of the Archipelago of São Pedro and São Paulo, Equatorial Atlantic.

\begin{tabular}{cccc}
\hline $\begin{array}{c}\text { Sample } \\
\text { number }\end{array}$ & $\begin{array}{c}\text { Area of } \\
\text { collection } \\
\text { in the cove }\end{array}$ & $\begin{array}{c}\text { Substrate } \\
\text { (Algae/ Sediment) }\end{array}$ & $\begin{array}{c}\text { Depth } \\
(\sim \mathrm{m})\end{array}$ \\
\hline M 1001-N & Area A & Algae (Caulerpa racemosa) & 2 \\
M 1002-N & Area A & Algae sp.1 & 2 \\
M 1003-N & Area A & Sediment & 5 \\
M 1004-N & Area A & Sediment & 5 \\
M 1005-N & Area A & Sediment & 5 \\
M 1008-N & Area A & Sediment & 5 \\
M 1010-N & Area A & Sediment & 10 \\
M 1011-N & Area A & Algae sp.1 & 3 \\
M 1012-N & Area B & Sediment & 11 \\
M 1014-N & Area B & Sediment & 11 \\
M 1017-N & Area A & Algae sp.1 & 2 \\
M 1018-N & Area A & Algae sp.1 & 2 \\
M 1021-N & Area A & Algae (Caulerpa racemosa) & 2 \\
M 1022-N & Area C & Algae sp.1 & 4 \\
M 1023-N & Area C & Algae (Caulerpa racemosa) & 4 \\
M 1025-N & Area C & Algae (Caulerpa racemosa) & 4 \\
M 1026-N & Area C & Algae sp. 2 & - \\
M 1030-N & Area C & Algae sp. 2 & 5 \\
M 1031-N & Area C & Algae (Caulerpa racemosa) & 5 \\
M 1032-N & Area C & Algae (Caulerpa racemosa) & 5 \\
M 1035-N & Area C & Algae (Caulerpa racemosa) & 5 \\
M 1036-N & Area C & Algae sp. 2 & 5 \\
\hline & & & \\
\hline
\end{tabular}

some empty carapaces were recovered together these algae. In the laboratory, the algal material was washed through a $0.250 \mathrm{~mm}$ mesh and all specimens (living and dead) were picked under stereomicroscope. Live specimens were stored in vials containing alcohol 70\%, and empty carapaces and isolated valves were glued in micropaleontological slides. Single valves were also counted as one specimen.

Each sediment sample, before washed and sieved through a mesh of $0.250 \mathrm{~mm}$ was fractionated to $20 \mathrm{ml}$. Procedures for the storage of living and dead specimens followed the same protocols above described for the algae material. Single valves were also counted as one dead specimen.

The ostracods herein examined are held in the collections of the 'Museu de Paleontologia', Universidade Federal do Rio Grande do Sul (UFRGS), Section of Ostracoda. The figured material is identified by the prefix MP-O. All SEM photographs were taken at the Centro de Microscopia Eletrônica' at UFRGS. The only specimen of the genus Cytherella was lost during preparation for SEM.

Morphological abbreviations: LV, left valve; RV, right valve; c, carapace; v, valve; $\uparrow$, female; $\hat{\sigma}$, male.

Faunal analysis. This work allowed the recognition of 14 species, 10 genera and eight families totalizing 5,552 specimens recovered from 18 samples, 11 of which were taken from seaweed areas and only seven from the bottoms covered exclusively by sediments (Tab. II; Figs 3-66). A group of four samples (seaweeds) was barren for ostracodes (M1018-N, M1021-N, M1022-N and M1035-N).

It is consensus among experts that shallow benthic marine ostracodes live in plants or sediments (see a review in WHATLEY \& WALL, 1975 for the relationship between ostracodes and seaweeds). However, it is also well known that many of them can be found alive in both substrates. In the cove of the ASPSP only the species of Paradoxostomatidae was recorded living exclusively or predominantly in areas covered by seaweeds. Xestoleberis sp. 1 was found surviving only in samples taken from areas covered exclusively by sediments. All remaining species, although they also occurred in vegetated areas, were most common in sediments.

Loxocorniculum tricornatum Krutak, 1971 is by far the most abundant ostracode species in the ASPSP (75.9\%) being represented by 1,150 living specimens and 3,064 isolated valves. Most of the living ones (1,056 specimens) were recovered from bottoms covered only by sediments. Keijcyoidea sp. and Xestoleberis sp. 2 were the second and third most abundant ostracodes herein recorded (9.7\% and 3.2\%, respectively), respectively, being their living specimens much more common in areas devoid of seaweeds (Tab. II).

Cytherella sp. and Triebelina sp. were recorded only by very few juvenile valves, mainly in sediments devoid of seaweeds. Paradoxostoma sp. 3, also equally very rare, registered two living specimens, being only one adult in a sample from a seaweed area. These three species are the rarest ostracodes recorded in the ASPSP.

The other two species of Paradoxostoma were recorded mainly from living specimens. Paradoxostoma sp. 1 dwells only in seaweed areas while Paradoxostoma sp. 2, although much more abundant in this same substrate, was also encountered living on bottoms covered only by sediments. This is not surprising since this genus belongs to the cosmopolitan family Paradoxostomatidae which is more diverse and abundant on plants.

For all species in this study, the dominance of juveniles on adults could be observed, except for Xestoleberis sp. 2. The living ostracodes represent 30\% of total specimens recovered, taken out Cytherella sp. and Triebelina sp. not found alive.

\section{TAXONOMY}

\section{Family Hemicytheridae \\ Subfamily Hemicytherinae}

\section{Berguecythere gen. nov.}

Type species: Berguecythere insularis sp. nov., by monotypy.

Diagnosis. A subquadrate to subrectangular hemicytherid genus with a surface covered by reticulate ornament whose peripheral fossae can be secondarily punctate. An ear-shaped ridge, which starts around the 
Tab. II. Occurrence and abundance of living and dead ostracode species recorded at the Archipelago of São Pedro and São Paulo, Equatorial Atlantic.

\begin{tabular}{|c|c|c|c|c|c|c|c|c|c|c|c|c|c|c|}
\hline Samples & 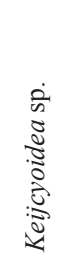 & 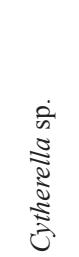 & 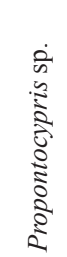 & $\begin{array}{l}\dot{2} \\
\tilde{0} \\
\tilde{\Xi} \\
\tilde{\Xi} \\
\tilde{\Xi} \\
z \\
z\end{array}$ & 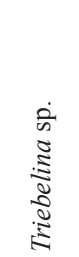 & 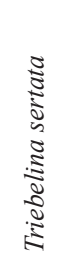 & 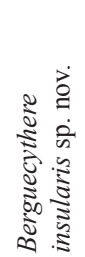 & 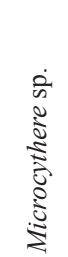 & 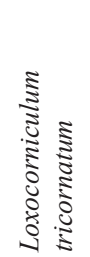 & 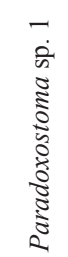 & 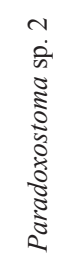 & 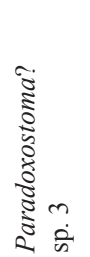 & 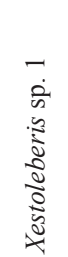 & 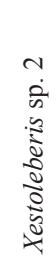 \\
\hline M 1001-N ${ }^{1}$ & - & - & - & - & - & - & - & $\mathrm{x}$ & - & - & - & - & - & $\mathrm{x}$ \\
\hline M $1002-N^{1}$ & - & - & - & - & - & - & - & - & - & - & - & - & - & $\mathrm{x}$ \\
\hline $\mathrm{M} 1003-\mathrm{N}^{2}$ & $\mathrm{x}$ & - & $\mathrm{x}$ & $\mathrm{x}$ & $\mathrm{x}$ & $\mathrm{x}$ & $\mathrm{x}$ & $\mathrm{x}$ & $\mathrm{x}$ & - & $\mathrm{x}$ & $\mathrm{x}$ & $\mathrm{x}$ & - \\
\hline $\mathrm{M} 1004-\mathrm{N}^{2}$ & $\mathrm{x}$ & - & $\mathrm{x}$ & $\mathrm{x}$ & $\mathrm{x}$ & $\mathrm{x}$ & $\mathrm{x}$ & $\mathrm{x}$ & $\mathrm{x}$ & $\mathrm{x}$ & $\mathrm{x}$ & - & $\mathrm{x}$ & $\mathrm{x}$ \\
\hline $\mathrm{M} 1005-\mathrm{N}^{2}$ & $\mathrm{x}$ & $\mathrm{x}$ & $\mathrm{x}$ & $\mathrm{x}$ & - & - & $\mathrm{x}$ & - & $\mathrm{x}$ & - & - & - & $\mathrm{x}$ & $x$ \\
\hline $\mathrm{M} 1008-\mathrm{N}^{2}$ & - & - & - & - & - & - & - & - & $\mathrm{x}$ & - & - & - & - & - \\
\hline $\mathrm{M} 1010-\mathrm{N}^{2}$ & $\mathrm{x}$ & - & $\mathrm{x}$ & $\mathrm{x}$ & - & $\mathrm{x}$ & $\mathrm{x}$ & $\mathrm{x}$ & $\mathrm{x}$ & - & $\mathrm{x}$ & $\mathrm{x}$ & $\mathrm{x}$ & $\mathrm{x}$ \\
\hline M 1011-N & $\mathrm{x}$ & - & - & - & - & - & - & - & $\mathrm{x}$ & - & - & - & - & $\mathrm{x}$ \\
\hline $\mathrm{M} 1012-\mathrm{N}^{2}$ & $\mathrm{x}$ & - & $\mathrm{x}$ & $\mathrm{x}$ & $\mathrm{x}$ & $\mathrm{x}$ & $\mathrm{x}$ & - & $\mathrm{x}$ & - & - & - & $\mathrm{x}$ & $\mathrm{x}$ \\
\hline M 1014- $\mathrm{N}^{2}$ & $\mathrm{x}$ & - & $\mathrm{x}$ & - & - & $\mathrm{x}$ & $\mathrm{x}$ & $\mathrm{x}$ & $\mathrm{x}$ & - & - & - & $\mathrm{x}$ & $\mathrm{x}$ \\
\hline M $1017-\mathrm{N}^{1}$ & - & - & - & - & - & - & - & - & - & - & - & - & - & $\mathrm{x}$ \\
\hline M $1023-\mathrm{N}^{1}$ & $\mathrm{x}$ & - & - & - & - & - & $\mathrm{x}$ & - & $\mathrm{x}$ & $\mathrm{x}$ & $\mathrm{x}$ & - & $\mathrm{x}$ & $\mathrm{x}$ \\
\hline M $1025-\mathrm{N}^{1}$ & $\mathrm{x}$ & - & $\mathrm{x}$ & $\mathrm{x}$ & - & $\mathrm{x}$ & - & $\mathrm{x}$ & $\mathrm{x}$ & - & $\mathrm{x}$ & $\mathrm{x}$ & $\mathrm{x}$ & $\mathrm{x}$ \\
\hline M 1026- $\mathrm{N}^{1}$ & - & - & - & - & - & - & - & - & - & - & - & $\mathrm{x}$ & - & - \\
\hline M $1030-\mathrm{N}^{1}$ & $\mathrm{x}$ & - & $\mathrm{x}$ & - & $\mathrm{x}$ & $\mathrm{x}$ & $\mathrm{x}$ & - & $\mathrm{x}$ & $\mathrm{x}$ & $\mathrm{x}$ & $\mathrm{x}$ & $\mathrm{x}$ & $\mathrm{x}$ \\
\hline M $1031-\mathrm{N}^{1}$ & $\mathrm{x}$ & - & $\mathrm{x}$ & $\mathrm{x}$ & - & - & $\mathrm{x}$ & - & $\mathrm{x}$ & - & - & - & $\mathrm{x}$ & $\mathrm{x}$ \\
\hline M 1032-N ${ }^{1}$ & $\mathrm{x}$ & - & - & - & - & - & $\mathrm{x}$ & - & $\mathrm{x}$ & - & $\mathrm{x}$ & - & $\mathrm{x}$ & $\mathrm{x}$ \\
\hline M 1036- $\mathrm{N}^{1}$ & $\mathrm{x}$ & - & $\mathrm{x}$ & $\mathrm{x}$ & - & - & - & $\mathrm{x}$ & $\mathrm{x}$ & $\mathrm{x}$ & $\mathrm{x}$ & - & $\mathrm{x}$ & $\mathrm{x}$ \\
\hline Living & 153 & - & 100 & 44 & - & 18 & 34 & 17 & 1,150 & 21 & 57 & 2 & 16 & 69 \\
\hline Dead (valves) & 386 & 1 & 73 & 68 & 6 & 45 & 44 & 2 & 3,064 & 3 & 9 & 4 & 56 & 110 \\
\hline Total & 539 & 1 & 173 & 112 & 6 & 63 & 78 & 19 & 4,214 & 24 & 66 & 6 & 72 & 179 \\
\hline Relative abundance \% & 9.71 & 0.02 & 3.12 & 2.02 & 0.11 & 1.13 & 1.40 & 0.34 & 75.9 & 0.43 & 1.19 & 0.11 & 1.30 & 3.22 \\
\hline
\end{tabular}

${ }^{1}$ Substrate covered by algae; ${ }^{2}$ Substrate covered by sediments.

central area, gives rise to a postero-dorsal protrusion. Internally, a very well-developed hemiamphidont hinge, the posterior terminal element of the RV being a dentate bar with 6-7 small teeth and a smooth distal area. Central muscle scars a row of four adductor with the dorso-median one subdivided; three frontal scars. Large duplicature with narrow anterior and posterior vestibular areas. Radial pore-canals numerous, straight, mostly simple with some intercalated branching ones.

Etymology. Berguecythere was named in honor to the Brazilian ostracodologist Cristianini Trescastro Bergue, a particular friend of the authors, in recognition of his precious contributions to the knowledge of fossil and Recent marine ostracodes.

Geographical and stratigraphical distribution. At present only in the ASPSP, Equatorial Atlantic.

\section{Berguecythere insularis sp. nov.}

(Figs 28-41)

Aurila sp. 1 Antonietto et al., 2012:42-43, Fig. 7: 10-19; Table 12.

Type material. Holotype, MP-O-2433, LV, , length: 0.44 $\mathrm{mm}$; height: $0.25 \mathrm{~mm}$. Paratypes. MP-O-2434, RV, ㅇ, length: 0.42 $\mathrm{mm}$; height: $0.23 \mathrm{~mm}$; MP-O-2435, RV,, , length: $0.42 \mathrm{~mm}$; height: $0.23 \mathrm{~mm}$; MP-O-2436, LV, 9 , length: $0.46 \mathrm{~mm}$; height: $0.25 \mathrm{~mm}$ MP-O-2437, LV, ô, length: $0.44 \mathrm{~mm}$; height: $0.23 \mathrm{~mm}$; MP-O-2438, $\mathrm{RV}$, ô, length: $0.43 \mathrm{~mm}$; height: $0.22 \mathrm{~mm}$; MP-O-2439, carapace, 우, width: $0.20 \mathrm{~mm}$; length: $0.44 \mathrm{~mm}$; MP-O-2440, carapace, ô, width: $0.18 \mathrm{~mm}$; length: $0.45 \mathrm{~mm}$; MP-O-2441, LV, juvenile, length: 0.37 $\mathrm{mm}$; height: $0.21 \mathrm{~mm}$; MP-O-2442, LV, juvenile, length: $0.31 \mathrm{~mm}$; height: $0.18 \mathrm{~mm}$; MP-O-2443, RV, juvenile, length: $0.25 \mathrm{~mm}$; height: $0.14 \mathrm{~mm}$; MP-O-2444, RV, o, length: $0.42 \mathrm{~mm}$; height: $0.23 \mathrm{~mm}$.

Etymology. From Latin origin, insularis $=$ of an island, because of its first record being restricted to an archipelago.

Type locality. Archipelago of São Pedro and São Paulo, Equatorial Atlantic.

Occurrence. See Table III.

Description. A thick-shelled genus of the subfamily Hemicytherinae, subquadrate to subrectangular in lateral view. Greatest height at the anterior cardinal angle. Anterior margin obliquely rounded. Posterior margin caudate in RV and subcaudate in LV. Dorsal margin somewhat convex in LV and subrectilinear in RV. Ventral margin with conspicuous oral concavity. Surface covered with reticulate ornament with the peripheral fossae secondarily gently punctate. A delicate ridge, which starts at the ventral end, runs parallel to the anterior margin, crosses the well-developed eye tubercle, and becomes more slender along the dorsal margin. An ear-shaped ridge starts around the central area and ascends to its heaviest width in front at the posterior 


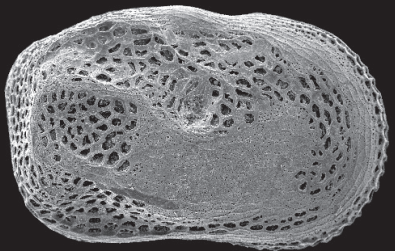

3

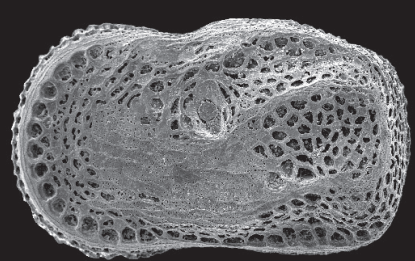

6
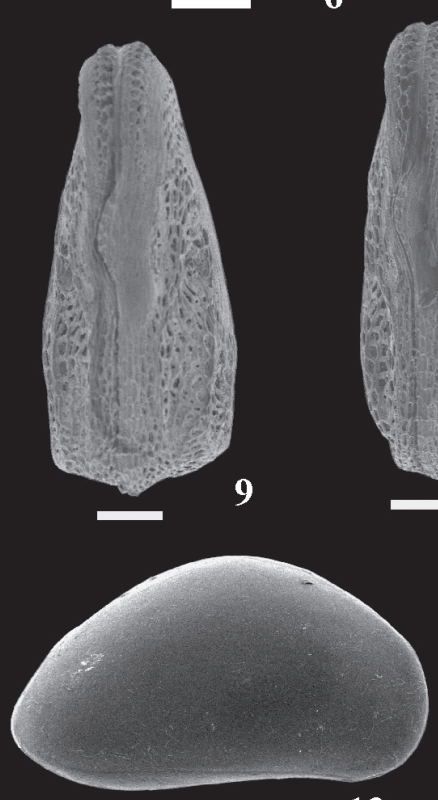

12

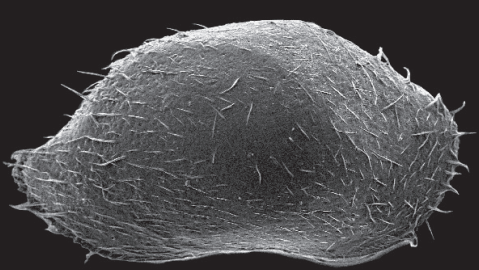

15

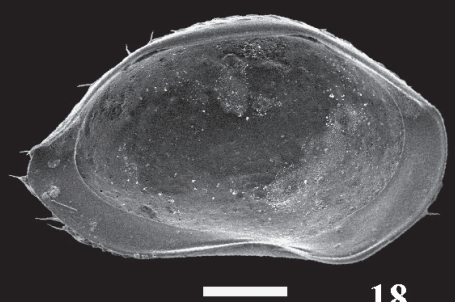

18

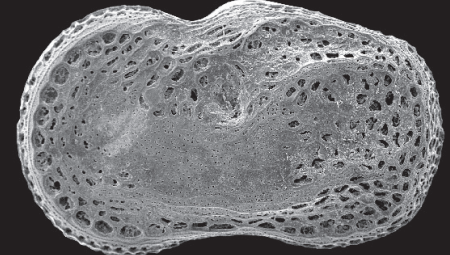

4
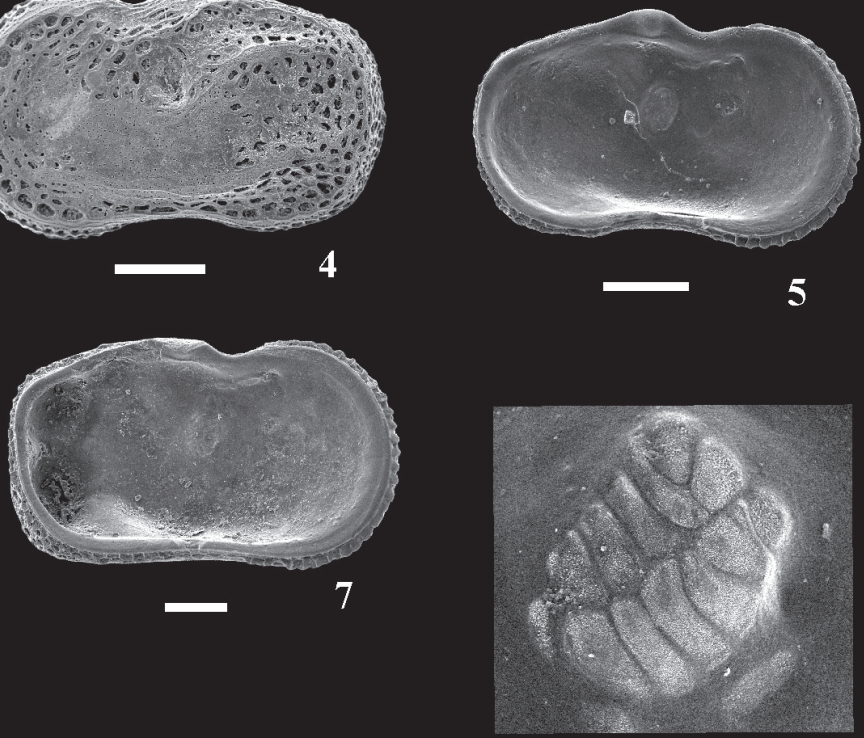

8

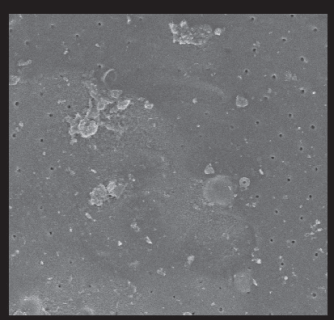

10

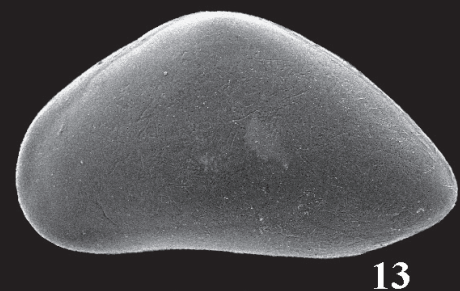

13

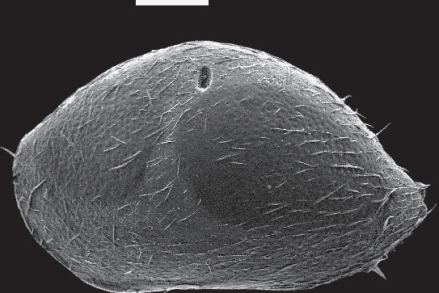

ए 16

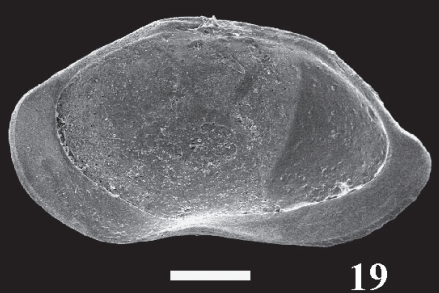

19
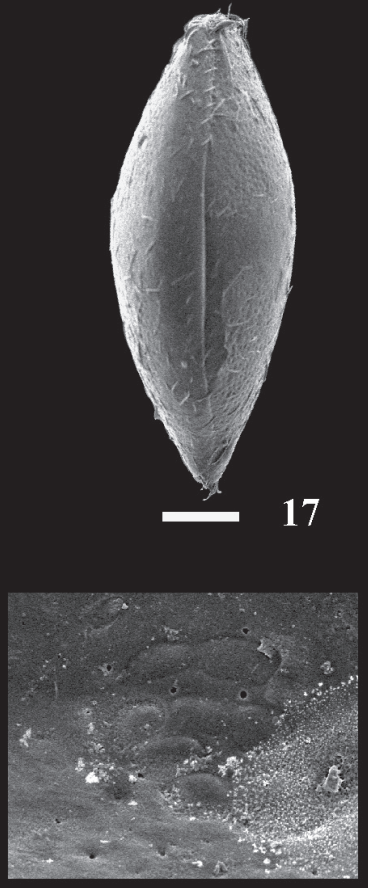

Figs 3-20. Keijcyoidea sp.: 3, MP-O-2411, RV, q; 4, MP-O-2412, LV, ð̊; 5, MP-O-2413, LV, ô, internal view; 6, MP-O-2414, LV, क; 7, MPO-2415, LV, + , internal view; 8, MP-O-2415, LV, +, central muscle scars, not in scale; 9, MP-O-2416, c, †, dorsal view; 10, MP-O-2417, c, ơ, dorsal view. Propontocypris sp.: 11, MP-O-2418, internal view; 12, MP-O-2419, RV; 13, MP-O-2420, LV; 14, MP-O-2418, central muscle scars, not in scale. Neonesidea sp.: 15, MP-O-2421, RV; 16, MP-O-2422, LV; 17, MP-O-2423, c, dorsal view; 18, MP-O-2424, LV, internal view; 19, MP-O-2425, RV, internal view; 20, MP-O-2425, central muscle scars, not in scale. The scale of all specimens $=100 \mu \mathrm{m}$, if no other indication. 


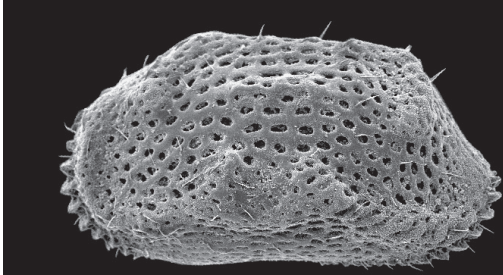

— 21
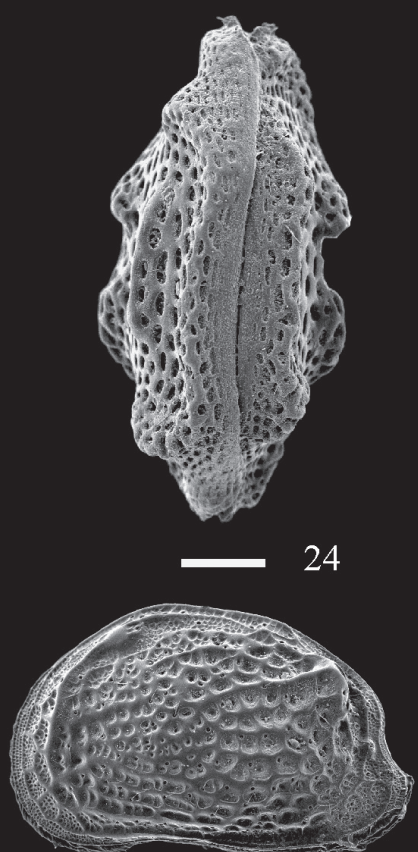

r 28
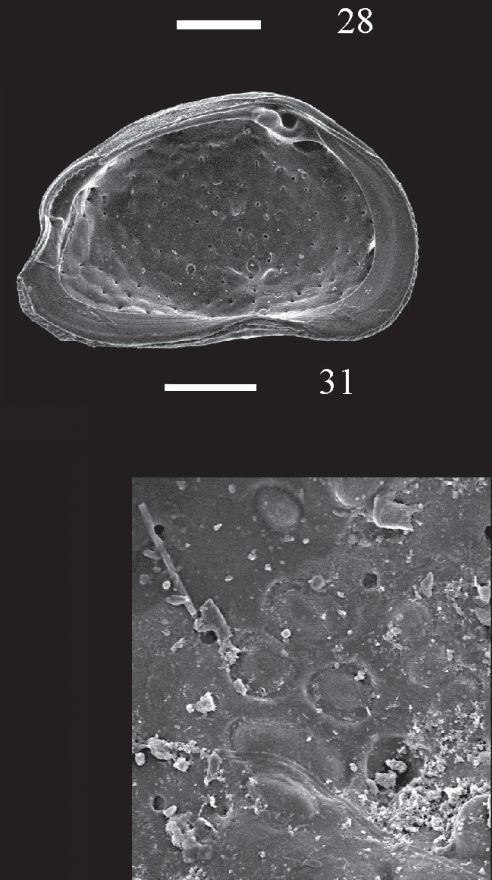

34

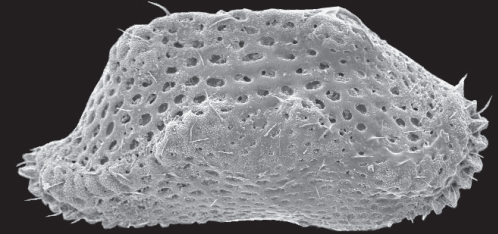

22

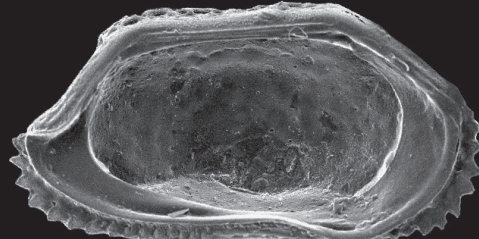

23

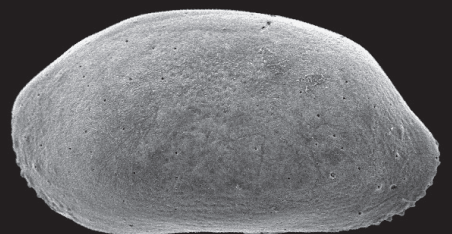

25

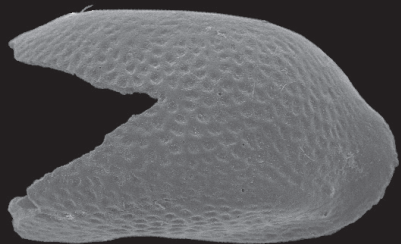

26
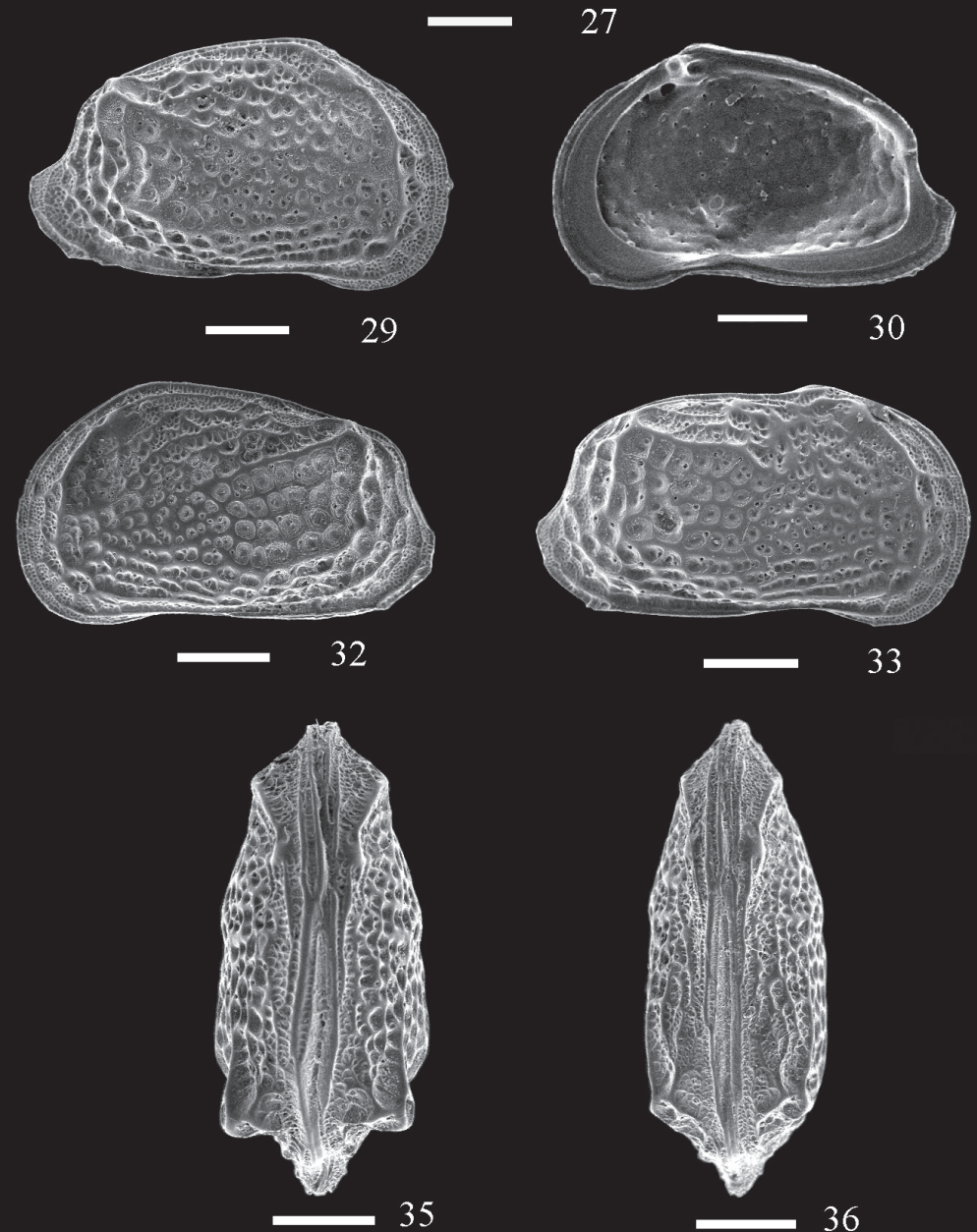

29

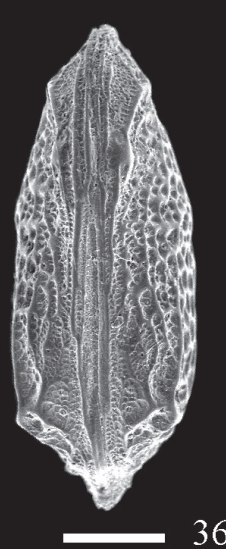

Figs 21-36. Triebelina sertata Triebel, 1948: 21, MP-O-2426, LV; 22, MP-O-2427, RV; 23, MP-O-2428, LV, internal, view; 24, MP-O-2429, c, dorsal view. Triebelina sp.: 25, MP-O-2430, LV; 26, MP-O-2431, LV; 27, MP-O-2432, RV, internal view. Berguecythere insularis gen. nov., sp. nov.: 28, MP-O-2433, LV, क्; 29, MP-O-2434, RV, + ; 30, MP-O-2435, RV, क, internal view; 31, MP-O-2436, LV, o, internal view; 32, MP-O2437, LV, 3 ; 33, MP-O-2438, RV, o; 34, MP-O-2436, LV,, , central muscle scars, not in scale; 35, MP-O-2439, c, 9 , dorsal view; 36, MP-O$2440, \mathrm{c}, \hat{\partial}$, dorsal view. The scale of all specimens $=100 \mu \mathrm{m}$, if no other indication. 
Tab. III. Occurrence of adults and juveniles of Berguecythere insularis gen. nov., sp. nov. in the cove of the Archipelago of São Pedro and São Paulo, Equatorial Atlantic.

\begin{tabular}{lccc}
\hline Sample & Substrate & Adults & Juveniles \\
\hline M1003- N & Sediment & $2 \mathrm{v}$ & $16 \mathrm{c} ; 5 \mathrm{v}$ \\
M1004- N & Sediment & $1 \mathrm{v}$ & $2 \mathrm{c} ; 4 \mathrm{v}$ \\
M1005- N & Sediment & - & $1 \mathrm{v}$ \\
M1010- N & Sediment & $2 \mathrm{v}$ & $5 \mathrm{c} ; 1 \mathrm{v}$ \\
M1012- N & Sediment & - & $4 \mathrm{c} ; 6 \mathrm{v}$ \\
M1014- N & Sediment & $1 \mathrm{v}$ & $5 \mathrm{c} ; 3 \mathrm{v}$ \\
M1023- N & Algae (Caulerpa racemosa) & - & $1 \mathrm{v}$ \\
M1025- N & Algae (Caulerpa racemosa) & $1 \mathrm{v}$ & $2 \mathrm{c} ; 6 \mathrm{v}$ \\
M1030- N & Algae sp. 2 & $1 \mathrm{v}$ & $5 \mathrm{v}$ \\
M1031- N & Algae (Caulerpa racemosa) & $1 \mathrm{v}$ & $2 \mathrm{v}$ \\
M1032- N & Algae (Caulerpa racemosa) & - & $1 \mathrm{v}$ \\
Total & & $9 \mathrm{v}$ & $34 \mathrm{c} ; 35 \mathrm{v}$ \\
\hline
\end{tabular}

cardinal angle. From there it descends as a short stretch and turns forward and then disappears near the midlength. This ear-shaped ridge gives rise to a posterodorsal protrusion more developed in RV. Normal porecanals sieve-type. In dorsal view acuminate anteriorly, maximum width posteriorly. In internal view, hinge robustly developed, hemiamphidont, the posterior terminal element of the RV being a dentate bar with 6-7 small teeth and a smooth distal area. Calcified inner lamella well-developed with narrow vestibulae at each end. Radial pore-canals numerous, straight, mostly simple with some intercalated branching ones. Selvage conspicuous and parallel to the outline. Adductor muscle scars a row of four scars, the dorso-median one subdivided. Three frontal scars. Sexual dimorphism conspicuous; male more elongate and less wide, and with a more secondarily reticulate dorsal region.

Remarks. The genus Tenedocythere Sissingh, 1972 (see a revision in BoNADUCE et al., 1986) is a tropical cosmopolitan hemicytherid genus with some external features in common with Berguecythere gen. nov. It has a coarse reticulate ornamentation, strongly dominating antero-posterior ribs and a peripheral rib that is frequently lacking posteriorly.
Tenedocythere does not have a hemiamphidont hinge and its central muscle scars consist of a vertical row of four subrectangular scars and two suboval frontal scars.

Falklandia, a hemicytherid monotypic genus described by WhatLey et al. (1987) from the southernmost South Atlantic, resembles somewhat Berguecythere gen. nov. and possesses a hemiamphidont hinge; however, the posterior terminal element of the RV is constituted exclusively by a dentate bar with 5-7 small oval teeth which increase in size distally. Furthermore, the two central adductor scars of Falklandia are subdivided. Externally, the two genera can be distinguished mainly by the reticulation with fossae secondarily punctate (four puncta per fossa is the most common) and the antero-lateral excrescence (in female LV) of Falklandia.

Finally, some of the more elongate species of Aurila Pokorný, 1955, resemble Berguecythere insularis sp. nov. Nevertheless, this new taxon does not have auriline dentition; possesses fewer radial pore-canals, some of which bifurcate distally; and features a well-developed postero-dorsal protrusion. Central muscle scars of Aurila a row of four adductors with the dorso-median, and rarely the ventro-median, divided into two; frontal scars three, sometimes only two (sec. HARRISON et al., 2000). Moreover, some years before, JELLINEK (1995) concluded that all species of Aurila have just the dorso-median adductor scar divided in two and three frontal scars. It is noteworthy that in that paper, which was unknown to HARRISON et al. (2000), JELLINEK (1995) discussed many similarities and dissimilarities of 11 hemicytherid (Aurilini) genera, and they all have Aurila-tooth (posterior anti-slip tooth in LV). Not only this hinge feature is absent in the new genus and new species herein described, as already discussed above, but also Berguecythere insularis sp. nov. has only the dorso-median adductor scar subdivided; the frontal scars are three in number.

Tab. IV. Comparison of the species identified in this paper and the ones registered by ANTONIETTO et al. (2012).

\begin{tabular}{|c|c|}
\hline This paper & ANTONIETTO et al. (2012) \\
\hline Keijcyoidea sp. & Keijcyoidea praecipua (Bold, 1963) \\
\hline Cytherella sp. & no recorded \\
\hline Propontocypris sp. & Propontocypris (Ekpontocypris) pirifera? (Mueller, 1894) \\
\hline Neonesidea sp. & Neonesidea tenera? (Brady, 1886) \\
\hline Triebelina sp. & Triebelina cf. intermedia Witte, 1993 \\
\hline Triebelina sertata Triebel, 1948 & Triebelina sertata Triebel, 1948 \\
\hline Berguecythere insularis gen. nov., sp. nov. & Aurila sp. 1 \\
\hline Microcythere sp. & Xestoleberis? sp. 3 \\
\hline Loxocorniculum tricornatum Krutak, 1971 & Loxoconcha (Loxocorniculum) tricornata (Krutak, 1971) \\
\hline Paradoxostoma sp. 1 & Paradoxostoma sp. 1 \\
\hline Paradoxostoma sp. 2 & Paradoxostoma sp. 2 \\
\hline Paradoxostoma? sp. 3 & no recorded \\
\hline Xestoleberis sp. 1 & Xextoleberis toni? Wouters, 2003 \\
\hline no recorded & Xestoleberis sp. 1 \\
\hline Xestoleberis sp. 2 & Xestoleberis sp. 2 \\
\hline
\end{tabular}




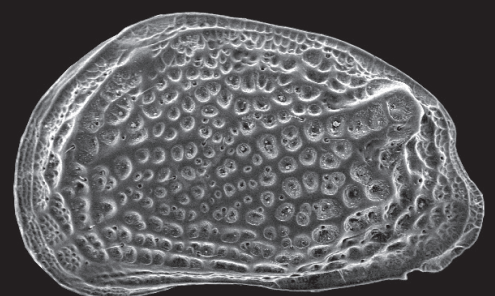

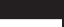

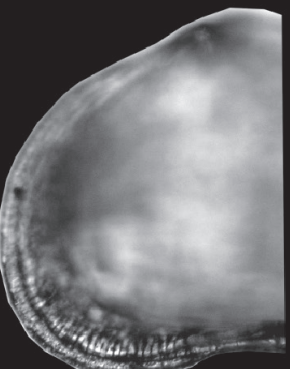

40

37

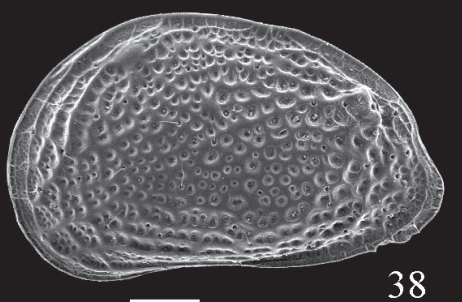

38
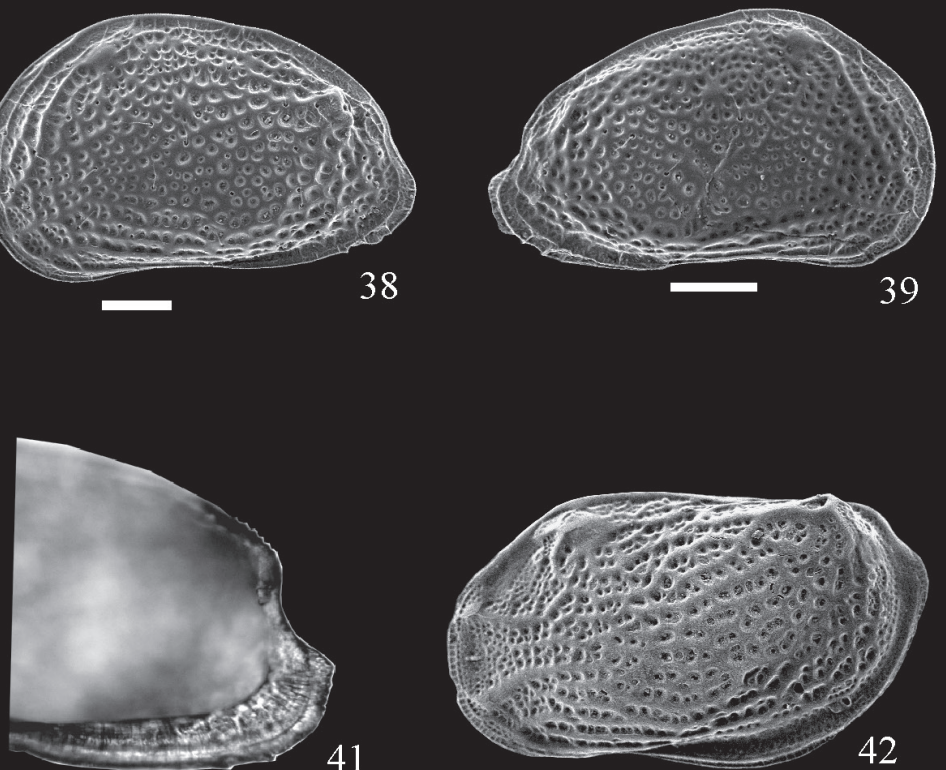

41
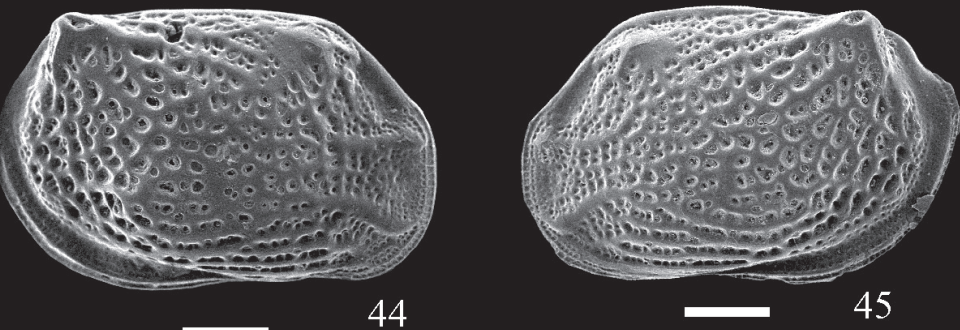

43
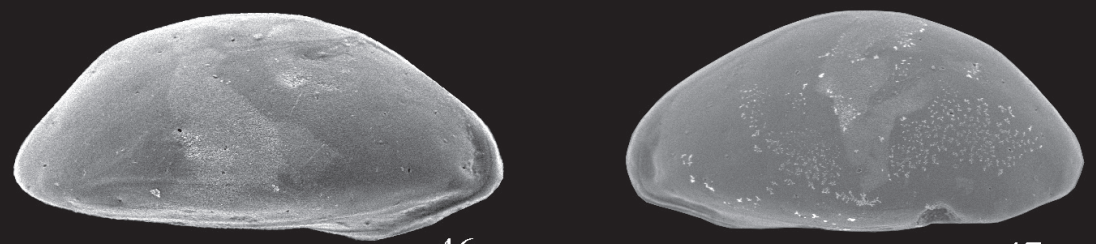

47
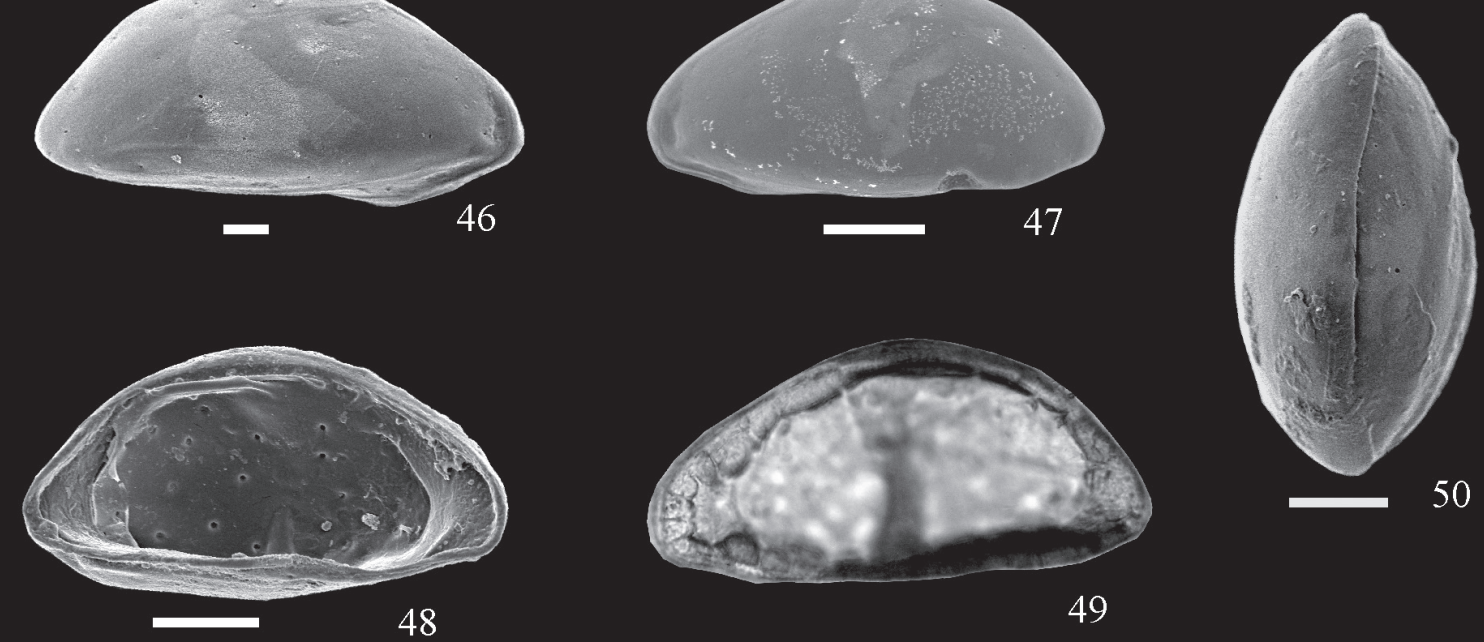

Figs 37-50. Berguecythere insularis gen. nov, sp. nov.: 37, MP-O-2441, LV, juvenile; 38, MP-O-2442, LV, juvenile; 39, MP-O-2443, RV, juvenile 40, MP-O-2444, RV,, , anterior marginal pore-canals, not in scale; 41, MP-O-2444, RV,, , posterior marginal pore-canals, not in scale. Loxocorniculum tricornatum Krutak, 1971: 42, MP-O-2445, LV, o, scale bar = $100 \mu \mathrm{m}$; 43, MP-O-2446, RV, ô, scale bar = $100 \mu \mathrm{m} ; 44, \mathrm{MP}-\mathrm{O}-2447$, RV, ㅇ, scale bar $=100 \mu \mathrm{m} ; 45$, MP-O-2448, LV, ㅇ, scale bar $=100 \mu \mathrm{m}$. Microcythere sp.: 46, MP-O-2449, RV, scale bar $=20 \mu \mathrm{m} ; 47, \mathrm{MP}-\mathrm{O}-2450$, LV; 48, MP-O-2451, LV, internal view; 49, MP-O-2452, RV, duplicature, transmitted light, not in scale; 50, MP-O-2453, c, dorsal view. The scale of all specimens $=50 \mu \mathrm{m}$, if no other indication. 


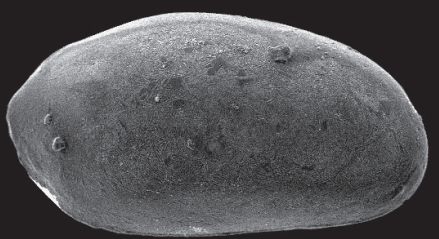

-51
$\square$

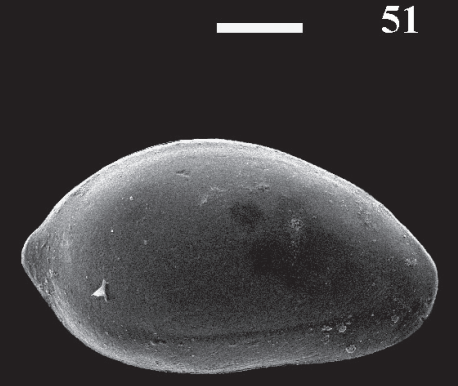

54
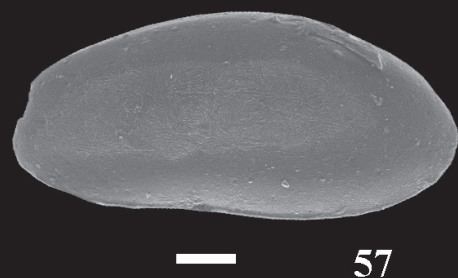

57

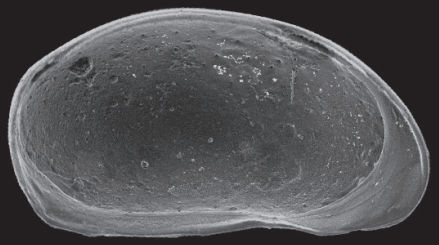

60
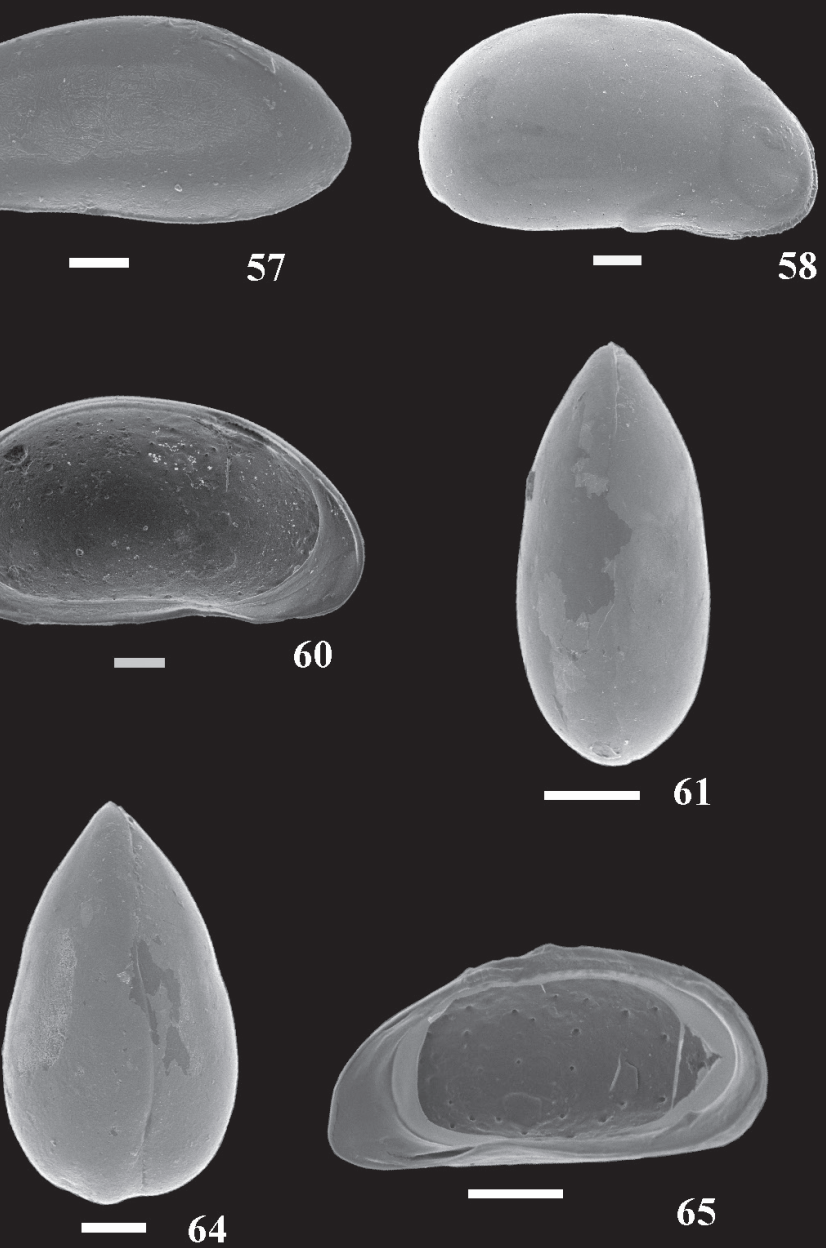

58
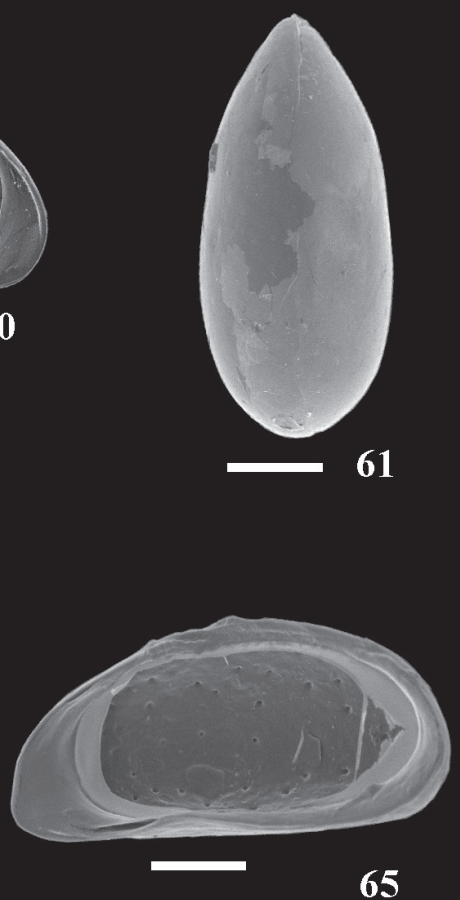

65

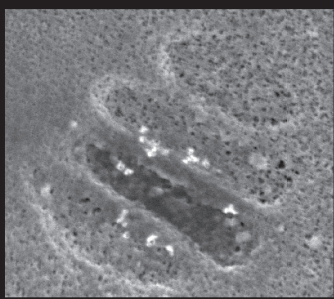

53
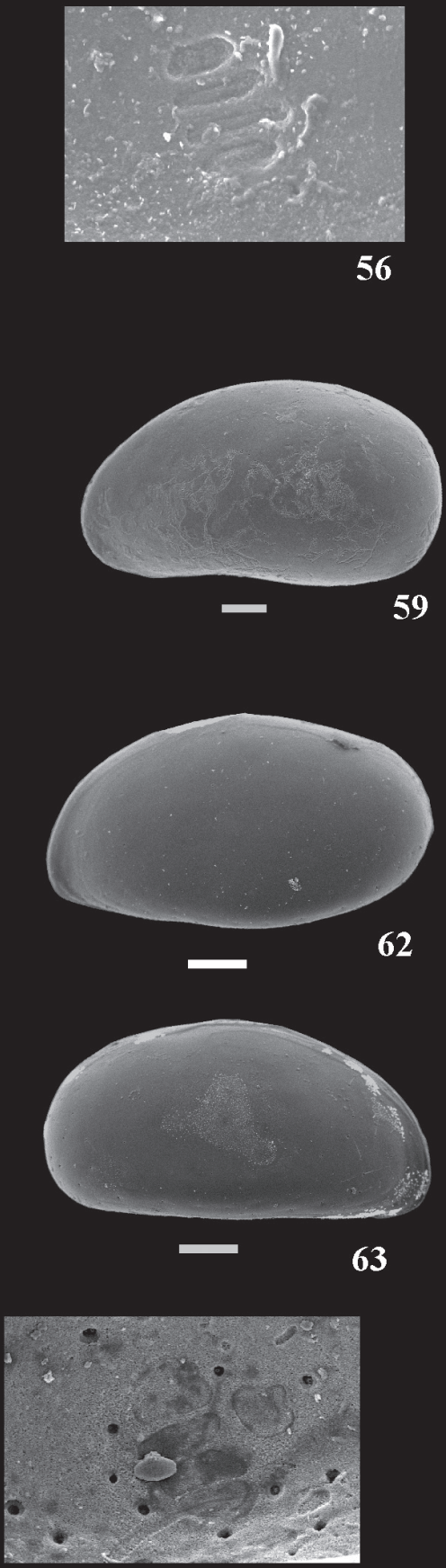

66

Figs 51-66. Paradoxostoma sp. 1: 51, MP-O-2454, RV, scale bar $=100 \mu \mathrm{m} ; 52$, MP-O-2455, RV, internal view, scale bar = $100 \mu \mathrm{m} ; 53$, MP-O-2455, RV, central muscle scars, not in scale. Paradoxostoma sp. 2: 54, MP-O-2456, RV; 55, MP-O-2457, LV; 56, MP-O-2457, LV, central muscle scars, not in scale. Paradoxostoma sp. 3: 57, MP-O-2458, LV. Xestoleberis sp. 1: 58, MP-O-2459, LV; 59, MP-O-2460, RV; 60, MP-O-2461, LV, internal view; 61, MP-O-2462, c, dorsal view, scale bar $=100 \mu \mathrm{m}$. Xestoleberis sp. 2: 62, MP-O-2463, RV; 63, MP-O-2464, LV; 64, MP-O-2465, c, dorsal view; 65, MP-O-2466, RV, internal view; 66, MP-O-2466, LV, central muscle scars, not in scale. The scale of all specimens $=50 \mu \mathrm{m}$, if no other indication. 


\section{DISCUSSION}

Taxonomic remarks. ANTONIETTO et al. (2012) published a preliminary identification of 13 species for the ASPSP. In the same work, they present synonymic lists and zoogeographical considerations. Except for Cytherella sp. and Paradoxostoma sp. 3, all the other species herein registered were also figured by Antonietto et al. (2012). However, it is believed that those authors have committed some misidentifications, as discussed below (see also Tab. IV).

ANTONietTo et al. (2012) presented an emended diagnosis to the species Keijcyoidea praecipua (Bold, 1963). According to those authors, the species herein presented as Keijcyoidea sp. would be co-specific with $K$. praecipua. In fact, as pointed out by them, the original material studied by BoLd (1963) was very poor (six specimens) with only one carapace which was described as male. ANTONIETTO et al. (2012) supposed that all Bold's specimens look very similar to the males of Keijcyoidea registered in the Archipelago of São Paulo and São Pedro, and believed that the true females of $K$. praecipua were described for the first time in their study. Furthermore, in the paper of ANTONIETTO et al. (2012), the material of Cytherelloidea praecipua Bold, 1963 figured and described by Allison \& Holden (1971), Swain \& Gilby (1974) and Teeter (1975) were considered co-specific with the specimens of Keijcyoidea recorded by them. However, in the opinion of the present authors, the material described and illustrated by ALLISON \& Holden (1971) possesses a quite different central muscle scars pattern, smaller dimensions (being much narrower in dorsal view), and conspicuous differences in ornaments. SwaIn \& GILBY (1974) figured a left side of a complete carapace of a large species identified by them as $C$. praecipua, but with a complete different size, outline and ornamentation when compared with the Bold's original material and the specimens illustrated and described by ANTONIETTO et al. (2012). TEETER (1975) presented a very poor figure of a male carapace that resembles the male figured by BOLD (1963) and possesses dimensions compatible with it. Although included in the synonymic list of ANTONIETTO et al. (2012), nothing was discussed by them about $C$. praecipua identified by Hulings (1967). However, the material studied by the latter author was not described and the two figures are so bad that, based only on them, it is impossible to make any comparison. Finally, the few specimens identified as K. praecipua by CoImBRA et al. (1992) are quite similar to that illustrated by BoLD (1963). Nevertheless, the left valve photographed has the reticulate row parallel to the anterior margin bearing a larger number of fossae being each fossa smaller than that presented in Bold's figures.

ANTONIETTO et al. (2012) recorded 109 specimens of propontocypridids identified as Pontocypris (Ekpontocypris) pirifera? (Mueller, 1894).
A comparison of that material with this species revealed important differences, including the outline, the number and pattern of the central muscle scars and the valve overlap. As has already been suggested by BotTEZINI \& MACHADO (2011), this species is probably new.

Neonesidea sp. was firstly identified by Antonietto et al. (2012) as Neonesidea tenera? (Brady, 1886) emended Maddocks, 1969. Moreover, the members of the informal group $N$. tenera, still insufficiently known, possess similar carapace morphology and until now it has been registered just outside of Atlantic waters. In the opinion of the present authors, further studies are necessary before Neonesidea sp. can be identified with confidence.

Triebelina sp. was tentatively identified by Antonietto et al. (2012) as Triebelina ef. intermedia Witte, 1963 based on one juvenile valve. The material herein recorded was also constituted only by few juveniles, so the attribution of these specimens to $T$. intermedia, even with some doubts, is precipitated.

Microcythere sp. was erroneously identified as Xestoleberis? sp. 3 by Antonietto et al. (2012). All its internal features fit well to the diagnosis of Microcythere Mueller, 1894.

AntoniEtTo et al. (2012) discussed the morphological similarities and dissimilarities among Xestoleberis sp. of CoImBra et al. (1992), Xestoleberis sp. of Keyser \& SchÖNING (2000) and Xestoleberis toni Wouters, 2003 and classified (with doubt) the species herein identified just as Xestoleberis sp. 1 as $X$. toni. However, in the opinion of the present authors Xestoleberis sp. 1 differs in outline and general shape compared with $X$. toni.

Zoo- and paleozoogeographical remarks. Marine benthic ostracodes have no planktotrophic larvae, and their dispersal and potential of colonization of isolated oceanic islands has important limiting factors, such as depth, changes in water temperature and duration of the journey (Cronin, 1988). Migration can be active or passive. Colonization of shallow marine areas occurs when active ostracodes migrate "step by step" from one region to another or by invasion and adaptation of deep water faunas (for the latter case see WHATLEY et al., 1997). For passive colonization have been suggested the following strategies: (i) the ostracodes "travel" on floating algae, their holdfasts and attached sediments from one location to another by surface currents; (ii) the ostracodes and/or their eggs are eaten by migratory seabirds (or transported in their feathers and feet as proposed by BoLD, 1976) and scattered along their routes; (iii) the transoceanic vessels transport and distribute ostracodes retained in their ballast water. However, TeETER (1973) proposed that only (i) and (iii) hypothesis are feasible. Regarding the hypothesis (ii), he considered it unlikely due to the depth in which benthic marine ostracodes live, the absence of desiccation resistant eggs in marine species, and the lack of correspondence between the routes of 
migratory birds and the distribution patterns of shallow marine ostracodes. TeETER (1973) also highlighted that other means of dispersal of benthic ostracodes reported in the literature, including the intestinal tract of fishes and transport by wind, are also unlikely. In the opinion of the present authors, the hypothesis (iii), although supported by TeEter (1973) and Witte (1993), is also not the main mechanism to explain many patterns of ostracode geographic distribution, since as shown by Cronin (1988), Coimbra et al. (1999) and Machado et al. (2005), to name only three examples, the study of fossils has revealed that many Recent species already had wide distribution before the advent of modern civilization.

The ostracode fauna from the ASPSP, when compared with other Atlantic isolated islands, shows a much smaller number of species. COIMBRA \& CARREÑo (2012), based on a small number of samples, recorded 21 ostracode species from Trindade Island $\left(20^{\circ} 30^{\prime} \mathrm{S}\right.$, $\left.29^{\circ} 18^{\prime} \mathrm{W}\right)$ and 23 species from Rocas Atoll $\left(03^{\circ} 52^{\prime} \mathrm{S}\right.$, $33^{\circ} 09^{\prime} \mathrm{W}$ ), while herein only 14 species were registered. WOUTERS (2003) described 13 species recovered from five intertidal samples collected from the island São Vicente $\left(16^{\circ} 36^{\prime} \mathrm{N}, 2^{\circ} 34^{\prime} \mathrm{W}\right)$, Archipelago of Cabo Verde. Thus, it is understood that the material of WOUTERS (2003) represents only a fraction of the total species of shallow marine Ostracoda inhabiting the more than ten islands and inlets of Cabo Verde.

VAN HARTEN \& WITTE (1993) attribute differences in ostracode diversity between East Atlantic and IndoWest Pacific to allopatric speciation controlled by sea level oscillations in the Neogene and Quaternary. The relation between area and faunistic diversity is an important factor controlling speciation of tropical shallow marine ostracodes, and may help explain for example why the Indo-West Pacific and the tropical West Atlantic are much more diversified than the East Atlantic. The East Atlantic is essentially a continuous continental margin with a comparatively uniform coastline while the first two are favored by an also vast but jugged coast as well as by several archipelagos, islets and seamounts (especially the Indo-West Pacific). Therefore, it is also very likely that the tiny area of the ASPSP together with its great isolation, contribute to the low diversity of ostracode registered there. Finally, it is worth remembering that the Trindade Island and Rocas Atoll are not only much larger than ASPSP, but also components of two chains of seamounts associated with the Trindade-Vitória Alignment and the Fernando de Noronha Fracture Zone, respectively (CoIMBRA \& CARreño, 2012). Thus, it was expected that these latter two oceanic islands have a greater diversity of Ostracoda than the ASPSP.

Triebelina sertata is the only species in common between ASPSP and the Trindade Island. This is a wellknown tropical cosmopolitan relict species whose origin is in the shallow-waters of the Indo-Pacific Ocean. In relation to the Rocas Atoll, two species are shared between the two islands: T. sertata and Loxocorniculum tricornatum. The last one is a species well known since the Miocene in the Caribbean region, and widely distributed in Recent sediments in the Gulf of Mexico, north and northeast of Brazil and the Rocas Atoll (Cormbra et al., 2009; Coimbra \& CARreño, 2012).Compared to Cabo Verde, apparently there are no species in common between the ASPSP and that archipelago. However, as already discussed above, further taxonomical studies are still needed on the shallow marine ostracodes of both Cabo Verde and the ASPSP.

It is worthy of note the absence of some tropical pandemic ostracodes such as Kotoracythere inconspicua (Brady, 1880) and Keijia demissa (Brady, 1868) in the material herein examined. Especially these two species are very well-known warm-water ostracode with numerous records in all oceans and even on the Brazilian (Coimbra \& Fauth, 2002) and African (Witte, 1993) warm-water shelves and in other Atlantic isolated tropical islands (e.g. Archipelago of Cabo Verde). However, despite being pandemic, these two species are normally a minor component in the ostracode faunas where they occur. Thus, considering the tiny area of the cove of the ASPSP and sampling effort carried out there, it is believed that $K$. inconspicua and $K$. demissa do not actually form part of the local benthic community.

\section{FINAL CONSIDERATIONS}

The benthic ostracode fauna of the cove of the ASPSP is not very rich, but considering the small area focused and the relatively large sampling effort carried out by this study, it is believed that the 14 species herein found closely represent the totality of species living there. The fact that (i) a significant number of species has been left in open nomenclature, (ii) one taxa is described as new genus and species (Berguecythere insularis), (iii) and the only two species already known to science (Loxocorniculum tricornatum and Triebelina sertata) have a large distribution in tropical oceans, strengthens the initial hypothesis that this ostracode fauna should possess a significant degree of endemism.

Considering the above discussion and the extensive review of the literature on living and Neocenozoic shallow-marine ostracodes conducted by the authors, it is very likely that the species left in open nomenclature represent new taxa. Thus, the endemism in the study area should be real in Ostracoda, as occurs for other better known benthic marine invertebrates (although less intense) from the ASPSP (see Moraes, 2011; VIEIRA et al., 2012). This endemicity could be explained especially by the absence of planktotrophic larval stages in marine benthic ostracodes and by the isolation of this archipelago, which unlike other Brazilian oceanic islands has no shallow submarine connections with the mainland, and is also far from other 
islands. Additionally, the system of surface currents of the Atlantic Ocean, although not explained in detail in this paper, should not lead to colonization of the ASPSP by passive dispersion of ostracodes on algae and associated holdfasts and sediments, which could also explain the absence of very common cosmopolitan shallow-water tropical species. However, this topic deserves further discussion in an ongoing research, which will also include the identification and description of the remaining species.

Acknowledgements. The authors are indebted to Fernando Erthal and Sandro Petró for their help in the field work activities. Sandro Petró is also acknowledged for his invaluable help with figures. The "Comissão Interministerial para os Recursos do Mar - SECIRM" and the "Universidade Federal do Rio Grande do Norte - UFRN" are acknowledged for logistical assistance. The authors also gratefully acknowledge the "Conselho Nacional de Desenvolvimento Científico e Tecnológico" (CNPq) for financial support (proc. 557144/2009-4 and 550054/2010-3), and the referee and editor for their constructive comments and recommendations.

\section{REFERENCES}

Allison, E. C. \& Holden, J. C. 1971. Recent ostracodes from Clipperton Island Eastern Tropical Pacific. Transactions of San Diego Society of Natural History 16:165-214.

Amaral, F. M. D.; Rocha, C. M. C.; Farrapeira, C. M. R.; Alves, M. S.; Pinto, S. L.; Lira, S. M. A.; Lima, K. K. M.; Ramos, C. A. C.; Santos, E. C. L.; Moura, J. R.; Oliveira, D. A. S.; Verçosa, M. M.; Melo, A. V. O. M.; Oliveira, A. P. A. \& Gonçalves, E. F. 2009. Distribuição espacial de invertebrados bentônicos infralitorais. In: Mohr, L. V. J.; CAstro, W. A.; Costa, P. M. S. \& AlvEs, R. J. eds. Ilhas oceânicas brasileiras: da pesquisa ao manejo. Brasília, Ministério do Meio Ambiente, IBAMA, v. 2. p. $148-156$.

Antonietto, L. S.; Machado, C. P.; Carmo, D. A. \& Rosa, J. W. C. 2012. Recent Ostracoda (Arthropoda, Crustacea) from São Pedro and São Paulo Archipelago, Brazil: a preliminary approach. Zootaxa 3335:29-53.

BOLD, W. VAN DEN. 1963. Upper Miocene and Pliocene Ostracoda of Trinidad. Micropaleontology 9:361-424.

1976. Distribution of species of the Tribe Cyprideidini (Ostracoda, Cytherideidae) in the Neogene of the Caribean. Micropaleontology 22:1-43.

Bonaduce, G.; Ruggieri, G. \& Russo, A. 1986. The genus Tenedocythere (Ostracoda, Podocopida) of the Mediterranean Miocene to Recent especially from Italy. Bollettino della Società Paleontologica Italiana 23:515-543.

BonatTi, E. 1990. Subcontinental mantle exposed in the Atlantic Ocean on St. Peter-Paul islets. Nature 345:800-802.

Bottezini, S. R. \& Machado, C. P. 2011. Estudo preliminar sobre ostracodes recentes do Arquipélago de São Pedro e São Paulo (ASPSP). In: Congresso Brasileiro de Paleontologia, 22, 2011. Atas, Natal, SBP/UFRN. p. 773-776.

Campos, T. F. C.; Petta, R. A.; Sichel, S. E.; Hartmann, L. A.; Theye, T.; Bezerra, F. H. R.; Srivastava, N. K. \& Mata, J. M. L. S. 2009. Estado da arte da geologia do Arquipélago de São Pedro e São Paulo (Atlântico Norte Equatorial Brasileiro). In: Mohr, L. V. J.; Castro, W. A.; Costa, P. M. S. \& Alves, R. J. eds. Ilhas oceânicas brasileiras: da pesquisa ao manejo. Brasília, Ministério do Meio Ambiente, IBAMA, v. 2. p. 55-80.

Coimbra, J. C. \& CARreño, A. L. 2012. Richness and palaeozoogeographical significance of the benthic Ostracoda (Crustacea) from the oceanic Island of Trindade and Rocas Atoll, Brazil. Revista Brasileira de Paleontologia 15:189-202.

Coimbra, J. C. \& Fauth, G. 2002. The families Bythocytheridae Sars, 1866 and Pectocytheridae Hanai, 1957 (Ostracoda) on the Brazilian equatorial shelf. Neues Jahrbuch Geologie und Paläontologie Monashefte 9:562-576.
Coimbra, J. C.; Ghilardi, V. G.; Casetta, G. M. \& Bergue, C. T. 2009. Ostracodes (Crustacea; Podocopida) da Ilha da Trindade e do Atol das Rocas, Brasil. In: Mohr, L. V. J.; Castro, W. A. CostA, P. M. S. \& Alves, R. J. eds. Ilhas oceânicas brasileiras: da pesquisa ao manejo. Brasília, Ministério do Meio Ambiente, IBAMA, v.2. p.125-141

Coimbra, J. C.; Pinto, I. D.; WÜrdig, N. L. \& Carmo D. A. 1999 Zoogeography of Holocene Podocopina (Ostracoda) from the Brazilian continental shelf. Marine Micropaleontology 37:365379.

Coimbra, J. C.; Ramos, M. I. F. \& Sanguinetti, Y. T. 1992. SubRecent ostracodes of the Tamandaré Bay, northeastern Brazil: a preliminary report on biofacies. Pesquisas 19:94-105.

Cronin, T. M. 1988. Geographical isolation in marine species: evolution and speciation in Ostracoda. In: HaNAI, T.; IKeYA, N. \& ISHIZAKI, K. eds. Evolutionary biology of Ostracoda: its fundamentals and applications. Kodansha, Elsevier. p. 871889.

Edwards, A. J. \& Lubbock, H. R. 1983. The ecology of Saint Paul's Rocks (Equatorial Atlantic). Journal of Zoology 200:51-69.

Harrison, D.; Maybury, C. \& Whatley, R. C. 2000. The ostracod genus Aurila from the Pliocene of north west France. Revista Española de Micropaleontología 32:21-60.

Hekinian, R.; Juteau, T.; Gracia, E.; Sicheler, B.; Sichel, S. E.; Udintsev, G.; Apprioual, R. \& Ligi, M. 2000. Submersible observations of Equatorial Atlantic Mantle: the St. Paul Fracture Zone Region. Marine Geophysical Researches 21:529-560.

Hulings, N. C. 1967. A review of the Recent marine podocopid and platycopidostracods oftheGulfofMexico.ContributionstoMarine Sciences 12:80-100

JellineK, T. 1995. The Plio-Pleistocene genus Mutilus Neviani, 1955 (Ostracoda) and some of its so-called Recent descendants. Senckenbergiana Lethaea 75:163-191.

KeYser, D. \& SchönInG, C. 2000. Holocene Ostracoda (Crustacea) from Bermuda. Senckenbergiana Lethaea 80:567-591.

Larwood, J. \& WhatLey, R. C. 1993. Tertiary to Recent evolution of Ostracoda in isolation on seamounts. In: MACKENZIE, K. G. \& JONES, P. eds. Ostracoda in the Earth and life sciences. Roterdam, Balkema. p.513-549.

Macedo-Soares, L. C. P.; Brandão, M. C.; KoettKer, A. G.; Menezes, B. S.; StumpF, L. \& Freire, A. S. 2009. Zooplâncton no Arquipélago de São Pedro e São Paulo. In: Mohr, L. V.; CAStro, J. W. A.; Costa, P. M. S. \& Alves, R. J. eds. Ilhas oceânicas brasileiras: da pesquisa ao manejo. Brasília, Ministério do Meio Ambiente, IBAMA, v. 2. p. 485-501.

Machado, C. P.; Coimbra, J. C. \& Carreño, A. L. 2005. The ecological and zoogeographical significance of the sub-Recent Ostracoda off Cabo Frio, Rio de Janeiro State, Brazil. Marine Micropaleontology 55:235-253.

Marinha do Brasil/SECIRM 2009. O Arquipélago de São Pedro e São Paulo: 10 anos de estação científica. Brasília, Ministério da Marinha, Secretaria Interministerial para os Recursos do Mar. $348 \mathrm{p}$.

Moraes, F. 2011. Esponjas das Ilhas Oceânicas Brasileiras. Rio de Janeiro, Museu Nacional. $252 \mathrm{p}$.

Moraes, F. \& Muricy, G. 2007. A new species of Stoeba (Demospongiae: Astrophorida) from oceanic islands off northeastern Brazil. Journal of the Marine Biological Association of the United Kingdom 87:1387-1393.

Moraes, F.; Batista, D.; Reis, F.; Monteiro, L.; Oliveira, M. \& MuRICY, G. 2009. As esponjas: passado, presente e futuro. In: Mohr, L. V. J.; Castro, W. A.; Costa, P. M. S. \& Alves, R. J. eds. Ilhas oceânicas brasileiras: da pesquisa ao manejo. Brasília, Ministério do Meio Ambiente, IBAMA, v. 2. p. 158-165.

Motoki, A.; Sichel, S. E.; Campos, T. F. C.; Srivastava, N. K. \& SoARES, R. 2009. Taxa de soerguimento atual do arquipélago de São Pedro e São Paulo, Oceano Atlântico Equatorial. Revista Escola de Minas 62:331-342.

Oliveira, P. S.; Martins-Silva, M. J.; Barros, J. C. N.; Swoboda, I.; Francisco, J. A.; Schneider, M.; Batista, J. C. L.; Aquino, P. P. U.; Viana, G. \& Coutinho, M. F. 2009. Malacofauna. In: Mohr, L. V.; Castro J. W. A.; Costa, P. M. S. \& Alves R. J. eds. Ilhas oceânicas brasileiras: da pesquisa ao manejo. Brasília, Ministério do Meio Ambiente, IBAMA, v. 2. p.174-185.

Sichel, S. E.; EsperanÇa, S.; Motoki, A.; Maia, M.; Horan, M. F.; 
Szatmari, P.; Alves, E. C. \& Mello, S. L. M. 2008. Geophysical and geochemical evidence for cold upper mantle beneath the Equatorial Atlantic Ocean. Revista Brasileira de Geofísica 26:69-86.

Stramma, L. \& England, M. 1999. On the water masses and mean circulation of the South Atlantic Ocean. Journal of Geophysical Research 104:20863-20883.

SwaIn, F. M. \& GiLBY, J. M. 1974. Marine Holocene Ostracoda from the Pacific coast of North and Central America. Micropaleontology 20:257-353.

TeEter, J. W. 1973.Geographic distribution and dispersal of some recent shallow-water marine Ostracoda. The Ohio Journal of Science73:46-54.

1975. Distribution of Holocene marine Ostracoda from Belize. In: Wantland, K. F. \& PuseY, W. C. eds. Belize shelf carbonate sediments, clastic sediments and ecology. American Association of Petroleum Geologists, Studies in Geology, v. 2. p. 400-499.

Van Harten, D. \& Witte, L. J. 1993. Centers of shallow marine origin and sea-level change. In: WitTE, L. J. ed. Taxonomy and origin of modern West African shallow marine Ostracoda. Proefschrift Vrije Universiteit Amesterdam. p. 165-173.
Vieira, L. M.; Farrapeira, C. M. R.; Amaral, F. D. \& Lira, S. M. A. 2012. Briozoan diversity in Saint Peter and Saint Pau Archipelago, Brazil. Cahiers de Biologie Marine 53:159-167.

Whatley, R. C.; Chadwick, J.; Coxill, D. \& Toy, N. 1987. New genera and species of Cytheracean Ostracoda from the SW Atlantic. Journal of Micropalaeontology 6:1-12.

Whatley, R. C.; Moguilevsky, A.; Toy, N.; Chadwick, J. \& Ramos, M. I. F. 1997. Ostracoda from the South West Atlantic. Part II The littoral fauna from between Tierra del Fuego and the Río de la Plata. Revista Española de Micropaleontología XXIX(2):583

Whatley, R. C. \& Wall, D. R. 1975. The relationship between Ostracoda and Algae in the littoral and sub-littoral marine environments. Bulletins of American Paleontology 65:173-203.

WitTE, L. J. 1993. Taxonomy and biogeography of West African beach ostracods. Verhandelingen Koninklijke Nederlandse Akademie van Wetenschappen, (Natuurkunde) 39:13-105.

Wouters, K. 2003. Taxonomy and zoogeography of intertidal Ostracoda (Crustacea) from the Cape Verde Islands (Atlantic Ocean). Bulletin Koninklijk Belgisch Instituut voor Natuurwetenschappen, Biologie 71:137-159. 